\title{
Pengaruh Konseling Kelompok Dengan Pendekatan Behavioral Terhadap Penyesuaian Diri Siswa Di MAS Salimpung
}

\author{
Jurmanisak $^{1}$ Wahidah Fitriani $^{2}$ \\ Program Studi Bimbingan dan Konseling Pendidikan Islam \\ Pascasarjana IAIN Batusangkar \\ Email: jurmanisak@gmail.com
}

\begin{abstract}
Abstrak
Masalah pokok dalam penelitian ini adalah rendahnya penyesuaian diri siswa di MAS Salimpaung.Tujuan dari penelitian ini adalah untuk melihat pengaruh konseling kelompok dengan pendekatan behavioral dalam meningkatkan penyesuaian diri siswa di MAS Salimpaung. Jenis penelitian ini adalah penelitian kuantitatif yang menggunakan rancangan pre experimental dengan tipe one group pretest-posttest design yaitu dengan mengukur penyesuaian diri kelompok eksperimen dengan menggunakan instrumen yang sama pada pengukuran pretest dan posttest. Teknik pengumpulan data yang penulis gunakan adalah skala. Populasi dalam penelitian ini adalah siswa kelas X MAS Salimpaung. Sampel pada penelitian ini adalah siswa kelas X Agama sebanyak 10 orang. Kelompok eksperimen ditentukan melalui teknik random sampling.
\end{abstract}

Kata Kunci:penyesuaian diri, konseling kelompok pendekatan behavioral

\begin{abstract}
The main problem in this study is the low adjustment of students in MAS Salimpaung. The purpose of this study is to look at the effect of group counseling with behavioral approaches in improving student adjustment in MAS Salimpaung. This type of research is a quantitative study that uses a pre-experimental design with the type of one group pretest-posttest design that is by measuring the adjustment of the experimental group using the same instrument in the pretest and posttest measurements. The data collection technique that I use is scale. The population in this study were students of class X MAS Salimpaung. The sample in this study was 10th grade students of Religion as many as 10 people. The experimental group was determined through a random sampling technique.
\end{abstract}

Keywords: personal adjustment, group counseling with behavioral approaches.

\section{PENDAHULUAN}

Penyesuaian diri merupakan hal yang penting dalam kehidupan individu. Penyesuaian diri akan selalu dilakukan individu dimanapun ia berada, baik di keluarga, sekolah, maupun masyarakat. Penyesuaian diri tidak hanya dengan lingkungan, tetapi penyesuaian diri juga dibutuhkan terhadap diri sendiri. Individu yang mampu menyesuaikan diri akan mudah menghadapi tuntutan lingkungan. Penyesuaian diri tidak hanya menyesuaikan diri dengan lingkungan, tetapi juga menyesuaikan lingkungan dengan keadaan diri sendiri.Penyesuaian diri sangat perlu dilakukan terutama di lingkungan sekolah. Pendidikan dan pengalaman yang dimiliki oleh seseorang baik di sekolah maupun di luar sekolah membuat dirinya memiliki pengetahuan tentang cara menyesuaikan diri dengan lingkungan. Hal ini sejalan dengan tujuan akhir dari hasil pendidikan individu, terletak pada kemampuannya dalam menyesuaikan diri dengan kebutuhan-kebutuhan hidup, dan tuntutan masyarakat.

Menurut Satmoko (dalam Ghufron \& Risnawita, 2011:50), "penyesuaian diri dipahami sebagai interaksi seseorang yang kontinu dengan dirinya sendiri, orang lain, dan dunianya".Penyesuaian diri merupakan salah satu ciri dari kepribadian yang sehat, yaitu kemampuan untuk menyesuaikan diri secara harmonis, baik terhadap diri sendiri maupun terhadap lingkungan.

Penyesuaian diri harus dilakukan di manapun dan kapanpun. Begitu juga halnya dengan siswa, ia harus mampu menyesuaikan diri dengan lingkungan sekolah. Menurut Kusdiyati, (2011:181) ciri-ciri penyesuaian diri di lingkungan sekolah antara lain:

1. Mau menerima dan menghormati otoritas sekolah 
2. Berminat dan berpartisipasi pada aktivitas sekolah

3. Membina relasi yang baik dengan teman sekolah, guru, dan unsurunsur sekolah

Dalam lingkungan sekolah penyesuaian diri sangatlah penting, apalagi hal yang berkenaan dengan peraturan sekolah.Bahwasanya tidak semua siswa yang mampu menyesuaikan dirinya dengan aturan sekolah terutama hal yang berkenaan dengan aturan berpakaian dan mematuhi tata tertib lainnya di sekolah.Dalam mematuhi aturan atau tata tertib di sekolah, tidak semua siswa mampu mematuhinya.Hal itu terlihat dari tingkah laku siswa yang melanggar aturan tersebut.

Ada beberapa dampak yang ditimbulkan akibat siswa tidak bisa menyesuaikan diri dengan baik, sebagaimana yang dikemukakan oleh Julianto, (2016:1) "Peserta didik menyontek saat ulangan, berkelahi dengan teman, berkata kasar kepada guru dan melanggar tata tertib sekolah, merupakan berbagai masalah yang muncul akibat peserta didik kurang mampu menyesuaikan diri di sekolah"

Pendapat lain juga dikemukakan oleh Aini (2014:106)Beberapa masalah yang terjadi pada siswa akibat tidak dapat menyesuaikan diri antara lain senang menyendiri, tidak mau menanggapi pendapat teman, kurang aktif dalam kelas, membolos, tidak masuk sekolah tanpa izin dan tanpa keterangan yang jelas, terlambat datang ke sekolah, lalai dalam mengerjakan tugas, mencontek, berpakaian tidak sesuai dengan peraturan sekolah dan merokok Dari kutipan di atas dapat dipahami bahwa dampak yang ditimbulkan akibat tidak bisanya siswa menyesuaikan diri tidak hanya dan membantu siswa menjadi pribadi yang lebiH mandiri. Salah satu jenis layanan konseling yaitu konseling kelompok. Dalam memberikan layanan konseling kelompok bisa diberikan dengan beberapa pendekatan, salah satunya yaitu pendekatan behavioral. Sebagaimana yang dikemukakan oleh Postuma dalam Sanyata, (2010:116) bahwa "pendekatan secara teoritis seperti client centered therapy, behavior therapy,

atau pendekatan behavioral

\section{METODOLOGI PENELITIAN}

Metode yang digunakan dalam penelitian ini yaitu metode eksperimen. Menurut Sugiyono, metode eksperimen dapat diartikan sebagai metode penelitian yang digunakan untuk mencari pengaruh perlakuan tertentu terhadap yang lain dalam kondisi yang terkendalikan (2013:72). Sedangkan menurut Kasiram, (2008:210) penelitian eksperimen yaitu "suatu model penelitian, dimana peneliti memanipulasi suatu stimuli atau kondisi, kemudian
4. Mau menerima tanggung jawab

5. Membantu sekolah mencapai tujuan

terlihat dari tingkah laku siswa yang tidak melanggar tata tertib sekolah.Siswa yang mencontek ketika adanya ujian, baik itu ulangan harian, tengah semester maupun ujian semester merupakan dampak akibat tidak bisanya siswa menyesuaikan diri di lingkungan sekolah. Dampak lain yang ditimbulkan yaitunya berkelahi dengan teman, serta berkata kasar kepada guru. Siswa yang tidak bisa menyesuaikan diri akan mengalami beberapa masalah dalam kehidupan sosialnya, seperti senang menyendiri. Siswa yang senang menyendiri hanya akan memperhatikan dirinya sendiri dan acuh dengan lingkungan sosialnya sehingga akan menimbulkan sikap ia tidak menghargai orang lain termasuk tidak menghargai pendapat temannya. Masalah lain yang terjadi pada siswa yang tidak bisa menyesuaikan diri dengan baik adalah kurang aktif di dalam kelas, membolos, tidak masuk sekolah tanpa ada keterangan, terlambat, lalai dalam mengerjakan tugas, melanggar aturan sekolah serta merokok.

Untuk membantu meningkatkan penyesuaian diri siswa di sekolah menjadi lebih baik bisa dibantu melalui layanan bimbingan dan konseling di sekolah.Hal ini sejalan dengan pendapat Putra (2014:6) bahwa "layanan bimbingan dan konseling dapat membantu siswa memberdayakan dirinya untuk mengembangkan penyesuaian diri yang baik dengan mengefektifkan konseling behavioral pada siswa".Tujuan konseling untuk membantu siswa mengatasi permasalahann

psychoanalythic therapy dan rational emotif therapy sebagai pendekatan yang dapat dipakai dalam perspektif kelompok". Jadi dapat dipahami bahwa pendekatan yang bisa digunakan dalam kegiatan kelompok, yaitu pendekatan client centered therapy, psychoanalythic therapy, rational emotif therapy serta behavior therapy mengobservasi pengaruh atau akibat dari perubahan stimuli atau kondisi tersebut pada objek yang dikenai stimuli atau kondisi tersebut".Dari pendapat di atas dapat dipahami bahwa penelitian eksperimen merupakan suatu metode penelitian yang dilakukan dengan memberi perlakuan kepada objek untuk melihat pengaruh suatu variabel terhadap variabel lainnya.Adapun rancangan atau desain dari penelitian ini yaitu Pre Experimental Design dengan tipe One Group Pretest-Posttest Design. 


\section{HASIL PENELITIAN DAN PEMBAHASAN}

Hasil Analisa Data dengan Statistik (Uji-t) Pre Test dan Post Test.

\begin{tabular}{|c|c|c|c|c|c|}
\hline \multirow{2}{*}{$\begin{array}{l}\mathbf{N} \\
\mathbf{0}\end{array}$} & \multirow{2}{*}{$\begin{array}{l}\text { Res } \\
\text { pon } \\
\text { den } \\
\end{array}$} & \multirow{2}{*}{$\begin{array}{c}\mathbf{Y}_{2} \\
\text { (Postest) }\end{array}$} & \multirow{2}{*}{$\begin{array}{c}\mathbf{Y}_{1} \\
\text { (Pretest) }\end{array}$} & \multirow{2}{*}{$\begin{array}{c}\mathbf{D} \\
\left(\mathbf{Y}_{2}-\right. \\
\left.\mathbf{Y}_{1}\right) \\
\end{array}$} & \multirow{2}{*}{$\begin{array}{c}D^{2} \\
\left(\mathbf{Y}_{2}-\right. \\
\left.\mathbf{Y}_{1}\right)^{2} \\
\end{array}$} \\
\hline & & & & & \\
\hline 1 & A & 138 & 120 & 18 & 324 \\
\hline 2 & HD & 147 & 99 & 48 & 2304 \\
\hline 3 & RN & 147 & 126 & 21 & 441 \\
\hline 4 & $\mathbf{J}$ & 94 & 71 & 23 & 529 \\
\hline 5 & IF & 122 & 71 & 51 & 2601 \\
\hline 6 & YL & 110 & 98 & 12 & 144 \\
\hline 7 & $\overline{\mathrm{SR}}$ & 144 & 83 & 61 & 3721 \\
\hline 8 & NR & 144 & 123 & 21 & 441 \\
\hline 9 & ID & 129 & 68 & 61 & 3721 \\
\hline 10 & YZ & 133 & 70 & 63 & 3969 \\
\hline \multicolumn{2}{|c|}{$\sum$} & 1308 & 929 & 379 & $\begin{array}{c}1819 \\
5\end{array}$ \\
\hline \multicolumn{2}{|c|}{ Rata-rata } & 130.8 & 92.9 & 37.9 & $\begin{array}{c}1819 . \\
5\end{array}$ \\
\hline
\end{tabular}

Penyesuaian Diri merupakan suatu kemampuan individu untuk beradaptasi dengan lingkungan.Penyesuaian diri merupakan mengubah diri sesuai dengan keadaan lingkungan, tetapi juga mengubah lingkungan sesuai dengan keadaan diri sendiri.Penyesuaian diri individu tidak selalu tinggi, namun penyesuaian diri individu juga bisa rendah.Penyesuaian diri individu yang rendah bisa ditingkatkan melalui layanan bimbingan dan konseling, salah satunya layanan konseling kelompok.

Berdasarkan hasil analisis data diperoleh hasil penelitian bahwa konseling kelompok dengan pendekatan behavioral berpengaruh signifikan dalam meningkatkan penyesuaian diri siswa di MAS Salimpaung.Berdasarkan hasil penelitian yang peneliti lakukan maka dapat dilihat hasilnya sebagai berikut.Pertama dilihat dari peningkatan skor antara pre-test dan post-test dan dilihat secara menyeluruh. Pada saat pre-test skor penyesuaian diri siswa yaitu 929 dengan ratarata 92,9 dengan rincian 1 orang siswa dengan kategori sangat tinggi, 2 orang siswa kategori tinggi, 3 siswa dengan kategori sedang dan 4 siswa dengan kategori rendah. Setelah dilakukan treatment hasil post-test didapatkan jumlah skor 1308 dengan rata-rata 130,8 dengan rincian 7 orang siswa pada kategori sangat tinggi, 2 siswa berada pada kategori tinggi dan 1 siswa pada kategori sedang. Jadi dapat dilihat bahwa penyesuaian diri siswa mengalami peningkatan setelah diberikan treatment.

Secara keseluruhan dapat dilihat bahwa hasilnya adalah Hipotesis alternatif $\left(\mathrm{H}_{\mathrm{a}}\right)$ diterima dan hipotesis nihil $\left(\mathrm{H}_{\mathrm{o}}\right)$ ditolak. Hal ini dilihat dari besarnya nilai " $t$ " yang diperoleh yaitu 5,81, sedangkan nilai $t_{t}$ yaitu 3,25. Ini berarti bahwa konseling kelompok dengan pendekatan behavioral berpengaruh signifikan dalam meningkatkan penyesuaian diri siswa di MAS Salimpaung pada taraf signifikansi $1 \%$.

Menurut Kurnanto, (2013:64-66) konseling kelompok dalam setting pendekatan behavioral, secara umum dilakukan dengan menempuh tiga tahap, yaitu:

1. Tahap permulaan, yang meliputi kegiatan-kegiatan sebelum terbentuknya kelompok konseling dan pertemuanperteuan pertama dari keseluruhan rencana konseling.

2. Tahap pelaksanaan, yaitu rancangan perlakuan bantuan dan penerapan teknik-teknik konseling

3. Tahap akhir. Pada tahap ini dilakukan perencanaan untuk tindak lanjut kegiatan kelompok.

Berdasarkan pendapat di atas dapat dipahami bahwa konseling kelompok dengan menggunakan pendekatan behavioral dilakukan dengan tiga tahap, yaitu tahap awal, tahap pelaksanaan dan tahap akhir. Pada tahap pelaksanaan teknik yang bisa digunakan menurut Natawidjaja, (2009:268) yaitu:

1. Penguatan kembali, dengan cara penghargaan, persetujuan, dukungan, dan perhatian.

2. Kontrak kontingensi, yaitu menjelaskan perilaku yang harus dilakukan, dirubah atau dihentikan.

3. Pemberian contoh

4. Gladi perilaku, bertujuan mempersiapkan konseli mampu melakukan atau menampilkan perilaku yang diinginkan yang telah diperoleh dalam kelompok.

Teknik yang terdapat di atas, merupakan ciri khas dari konseling yang menggunakan pendekatan behavioral terutama gladi perilaku.Pada teknik gladi perilaku dilakukan dengan mempraktekkan tingkah laku yang telah dipelajari sebelumnya pada kegiatan konseling.Pada teknik kontrak kontingensi juga dijelaskan pada klien perilaku yang harus dilakukan, yang harus dirubah ataupun perilaku yang harus dihentikan.

Setiap individu memiliki penyesuaian diri yang berbeda-beda.Penyesuaian diri yang baik perlu dimiliki individu dalam menjalani kehidupannya sehari-hari terutama di lingkungan sekolah. Menurut Kusdiyati (2011:181) ciri-ciri penyesuaian diri di lingkungan sekolah yaitu:

1) Mau menerima dan menghormati otoritas sekolah

2) Berminat dan berpartisipasi pada aktivitas sekolah

3) Membangun hubungan yang baik dengan teman sekolah, guru, dan unsurunsur sekolah

4) Mau menerima tanggung jawab

5) Membantu sekolah mencapai tujuan

Untuk meningkatkan penyesuaian diri siswa di sekolah, maka salah satu tugas guru BK/konselor di sekolah adalah melakukan 
layanan konseling kelompok dengan berbagai pendekatan yang ada.Salah satunya dengan menggunakan layanan konseling kelompok dengan pendekatan behavioral.

\section{SIMPULAN}

Berdasarkan hasil penelitian dan pembahasan tentang pengaruh konseling kelompok dengan pendekatan behavioral dalam meningkatkan penyesuaian diri siswa dapat disimpulkan bahwa konseling kelompok dengan pendekatan behavioral berpengaruh signifikan dalam meningkatkan penyesuaian diri siswa di MAS Salimpaung.

\section{DAFTAR PUSTAKA}

Aini, N. DYP. Sugijarto.Sutoyo, A. 2014.Pengembangan Model Bimbingan Kelompok dengan Teknik Sosiodrama untuk Meningkatkan Penyesuaian Diri Siswa.Jurnal Bimbingan Konseling. 3(2): 106

Kusdiyati, S. Halimah, L. Faisaluddin. 2011. Penyesuaian Diri di Lingkungan Sekolah pada Siswa Kelas XI SMA Pasundan 2 Bandung.Jurnal Humanitas. 8(2): 181
Kurnanto, E. 2013.Konseling Kelompok. Bandung: Alfabeta

Kasiram. 2008. Metode Penelitian. Yogyakarta: UIN Malang Press

Natawidjaja, R. 2009. Konseling Kelompok Konsep Dasar dan Pendekatan. Bandung: Rizqi Press

Putra, Agus Dharma. Ni Ketut Suarni, Dewi Arum WMP. 2014. Efektifitas Konseling Behavioral dengan Teknik Modeling untuk Mengoptimalkan Penyesuaian Diri Siswa Kelas X SMK Negeri 2 Singaraja. E-journal Undiksa Jurusan Bimbingan dan Konseling. 2(1): 6

Risnawita, R dan Gufran, M.N. 2011. Teori-teori Psikologi. Yogyakarta:Ar-Ruzz Media

Sugiyono. 2013. Metodologi Penelitian Kuantitatif, Kualitatif dan $R \& D$. Bandung: Alfabeta

Sanyata, S. Teknik dan Strategi Konseling Kelompok. 2010. Jurnal Paradigma. 5(09): 116 